\title{
Oral Mucormycosis and Aspergillosis in the Patient with Acute Leukemia
}

\section{Oralna mukormikoza i aspergiloza kod bolesnika s akutnom leukemijom}

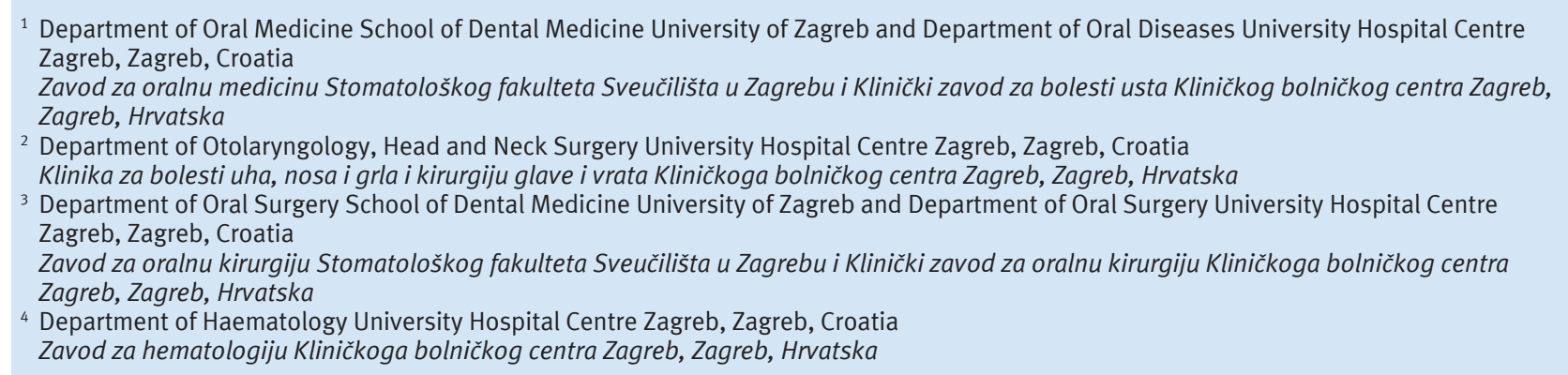

Abstract

A 54-year-old male patient with acute lymphoblastic leukemia was referred to the Department of Oral Medicine. He had a primary refractory disease and was treated according to HOVON71 and HAM protocol. Sixteen days after the start of the HAM protocol the patient developed palatal dark red/brownish lesion and maxillary vestibular exophytic lesion. Biopsy specimens from oral lesions were taken and microbiologic evaluation confirmed the presence of Aspergillus fumigatus and Rhizopus genus. The treatment of the patient consisted of the inferior maxillectomy and intravenous posaconazole and amphotericine B for the following 28 days. Since the coinfection with Aspergillus and Rhizopus is extremely rarely seen in the oral cavity, a diagnostic and therapeutic dilemma easily presents itself.
Received: November 23, 2018

Accepted: August 28, 2019

Address for correspondence Assist. Prof Danica Vidović Juras, DMD, MSc, PhD

Department of Oral Medicine School of Dental Medicine University of Zagreb Gundulićeva 5, 10000 Zagreb Tel: 003854802124 dvjuras@gmail.com

Key words Mouth Diseases; Mucormycosis; Aspergillosis; Immunocompromised Host; Leukemia

\section{Introduction}

Invasive fungal infections are the major cause of infection-related mortality in hematopoietic stem cells recipients. Although mucormycosis and aspergillosis are the most frequent fungal infections, coinfection in the same host occurs rarely (1). Furthermore, they can be frequently fatal in immunocompromised patients. Treatment options usually combine medical and surgical approaches, often including extended necrosectomies. Nevertheless, the prognosis of generalized fungal infections is very poor (2).

There have been several case reports describing combined aspergillosis and mucormycosis in various parts of the body, usually with a fatal outcome (3). However, one case report depicts a patient with relapsed acute myeloid leu-
Uvod

Kod primatelja krvotvornih matičnih stanica invazivne gljivične infekcije glavni su uzrok smrtnosti povezane $s$ infekcijom. Iako su mukormikoza i aspergiloza najčešće među njima, koinfekcija kod istog domaćina je rijetka (1). Nadalje, one često mogu biti kobne kad je riječ o imunokompromitiranim bolesnicima. U liječenju se obično kombiniraju medicinski i kirurški pristupi, često uključujući i opsežne nekrektomije. Unatoč tomu, prognoza generaliziranih gljivičnih infekcija veoma je loša (2).

Nekoliko je prikaza slučajeva u kojima se opisuju kombinirana aspergiloza i mukormikoza različitih dijelova tijela, obično sa smrtnim ishodom (3). No jedan prikaz slučaja opisuje bolesnika s relapsom akutne mijeloidne leukemije 
kemia with a combined Aspergillus and Mucorales infection (lungs, brain, spleen and bone) who has been a long time survivor (4). The aforementioned coinfection rarely occurs in healthy individuals. The case of a 22- year- old, otherwise healthy US Marine who sustained extensive soft tissue injuries was published (5). Additionally, Pozo-Laderas et al. (6) published a case of a 17-year- old immunocompetent male who developed this coinfection 11 days after a motorcycle accident.

The coinfection of mucormycosis and aspergillosis should be considered in immunosuppressed patients in order to establish early management that will lead to the improved prognosis of the patient (1).

\section{Case report}

A 54-year-old male patient was referred to the Department of Oral Medicine due to the dark red/brownish lesions on the left side of the palate (Figure 1) and vestibular exophytic, later ulcerative, lesion in the area of the teeth 25 27 (Figure 2). The lesion was well demarcated from the surrounding tissue, asymmetric and without hemorrhage.

He was diagnosed in December 2017 with acute lymphoblastic leukemia ( $\mathrm{Ph}$ negative and pre-B). He had primary refractory disease and was treated according to protocols HOVON71 (7) and HAM (high dose of cytosine arabinoside and mitoxantrone). During HAM protocol induced aplasia, the patient developed neutropenic colitis and Aspergillus niger was identified in his stool samples. At the time of the oral examination, the patient was treated with intravenous levofloxacin, acyclovir, metronidazole, collistine, meropenem and tigecycline.

Oral lesions appeared sixteen days after the start of the HAM protocol. The patient noticed a swelling of his left cheek. The abovementioned oral lesions were identified upon examination. The orthopantomograph (Figure 3) showed a radiopaque lesion within the left maxillary sinus. Teeth 23 , 26 and 27 were avital and tooth 24 was vital. Increased loosening of these teeth was noticed. A severe form of periodontal disease was present. The patient had no pain in that area, except sometimes on palpation. No evident pathological peri- $s$ kombiniranom infekcijom aspergilusom i mukoralesom (pluća, mozak, slezena i kosti) koja dugo preživljava (4). Spomenuta koinfekcija rijetko se pojavljuje kod zdravih pojedinaca. Objavljen je slučaj 22-godišnjeg, inače zdravog američkog marinca, koji je zadobio opsežne ozljede mekih tkiva (5). Uz to, Pozo-Laderas i suradnici (6) objavili su slučaj 17-godišnjeg imunokompetentnog mladića kod kojega se pojavila ta koinfekcija 11 dana nakon motociklističke nesreće.

Pri razmatranju imunosuprimiranih bolesnika u obzir treba uzeti koinfekciju mukormikoze i aspergiloze kako bi se što prije počelo sa zbrinjavanjem, a što će omogućiti bolju prognozu za bolesnika (1).

\section{Prikaz slučaja}

54-godišnji pacijent upućen je u Zavod za oralnu medicinu zbog tamnocrvene/smećkaste lezije na lijevoj strani nepca (slika 1.) i vestibularne egzofitične, poslije ulcerativne lezije u regiji zuba od 25 do 27 (slika 2.). Lezija je bila dobro ograničena od okolnog tkiva, asimetrična i nije bila praćena krvarenjem.

U prosincu 2017. bolesniku je dijagnosticirana akutna limfoblastična leukemija ( $\mathrm{Ph}$ negativan i pre-B). Imao je primarnu refraktornu bolest i liječen je prema protokolima $\mathrm{HO}$ VON 71 (7) i HAM (visoka doza citozin arabinozida i mitoksantrona). Tijekom aplazije izazvane protokolom HAM, bolesnik je razvio neutropenični kolitis i u uzorcima stolice identificiran je Aspergillus niger. U vrijeme oralnog pregleda bolesnik je bio liječen intravenski levofloksacinom, aciklovirom, metronidazolom, kolistinom, meropenemom i tigeciklinom.

Oralne lezije pojavile su se šesnaest dana nakon početka protokola HAM kada je bolesnik uočio oteklinu na lijevom obrazu. Gore navedene oralne lezije identificirane su pregledom. Ortopantomogram (slika 3.) pokazao je radioopaktnu leziju unutar lijevoga maksilarnog sinusa. Zubi 23, 26 i 27 bili su avitalni, a zub 24 vitalan. Uočena je pojačana pomičnost tih zuba. Bila je prisutna i izrazita parodontna bolest. Bolesnik nije imao bolove u tom području, osim katkad pri pal-
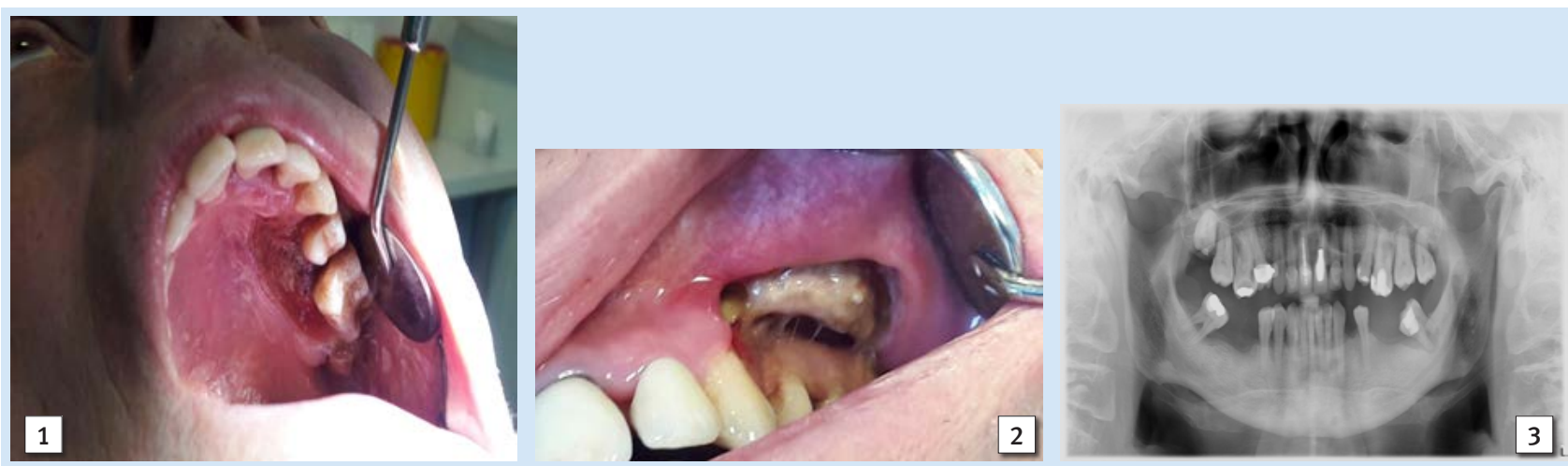

Figure 1 Palatal mucormycosis and aspergillosis: the dark red/brownish lesions on the left side of the palate

Slika 1. Palatalna mukormikoza i aspergiloza: tamna crveno/smećkasta lezija na lijevoj strani nepca

Figure 2 Vestibular mucormycosis and aspergillosis: the vestibular ulcerative lesion in the area of the teeth 25-27

Slika 2. Vestibularna mukormikoza i aspergiloza: vestibularna ulceracija u regiji zuba 25-27

Figure 3 Orthopantomograph showed a radiopaque lesion within the left maxillary sinus

Slika 3. Ortopantomogram je pokazao radioopaktnu leziju unutar lijevog maksilarnog sinusa 
apical pathology within teeth could be noticed. A CT finding showed a non-homogenous bony structure within the maxillary alveolar ridge.

Incisional biopsy of a vestibular lesion was taken. Histopathology showed tissue necrosis together with adipose tissue abundant with fungal hyphae and spores. Microbiological evaluation confirmed the presence of Aspergillus fumigatus and Rhizopus genus.

Intravenous posaconazole and amphotericine B were given for the following 28 days and inferior maxillectomy was performed. The maxillary defect was to be reconstructed after the completion of hematological treatment. Meanwhile, the patient was given an obturator. Due to poor general condition of the patient, further treatment of leukemia by the transplantation of alogenous stem cells was not possible. Therefore, the treatment with blinatumomab was initiated. Unfortunately, in June 2018, the patient died due to severe hemorrhagic shock and cardiopulmonary arrest.

Since the coinfection with Aspergillus and Rhizopus extremely rarely occurs in the oral cavity, it leads easily to the diagnostic and therapeutic dilemma.

\section{Discussion}

Acute invasive fungal infections in the paranasal sinuses and surrounding tissues are progressive and carry a high death rate in an immunocompromised patient (8). Gode et al. (8) described 37 patients with acute invasive fungal rhinosinusitis and reported that the palatal involvement was significantly associated with death rate.

There are only a few case reports about a concomitant aspergillosis and zygomicosis infection in the orofacial region $(1,2,9)$.

Torres-Damas et al. (1) reported a case of a 78-year-old male patient with type 2 diabetes and ketoacidosis who presented with a swelling of the right side of his face, right facial paralysis, ptosis and a necrotic ulcer on the right palate due to the Aspergillus fumigatus and mucormycosis. Chermetz et al. (2) reported the case of a 17-year-old girl with combined aspergillosis and mucormycosis of the right side of her face with frontal maxillary area and upper airway involvement after the treatment of a recurrent glioma.

Maiorano et al. (9) reported a case of aspergillosis and mucormycosis in the patient with stage-IV Castleman disease who presented with a palatal ulceration that progressively involved the palatal mucosa and bone, the paranasal sinuses and the orbit.

Although invasive fungal infections are the major cause of infection-related mortality in hematopoietic stem cells recipients, in this particular patient invasive fungal infection occurred prior to the hematopoietic stem cell transplantation, during the period of post-chemotherapy aplasia.

Differential diagnosis of such cases includes malignancy and because of that, biopsy is mandatory. Due to high frequency of fungal infections in immunocompromised patients, microbiological testing and identification of a causative organism should be performed.

Treatment of these lesions includes surgical resection of the affected tissues as well as intravenous antifungals. paciji. Nije se mogla uočiti periapeksna patologija zuba. CT nalaz pokazao je inhomogenu koštanu strukturu alveolarnog grebena maksile.

Učinjena je incizijska biopsija vestibularne lezije. Histopatološki nalaz pokazao je nekrotično vezivno i masno tkivo prožeto hifama i sporama gljivica. Mikrobiološkom analizom identificirani su u uzorku Aspergillus fumigatus i Rhizopus spp.

Tijekom sljedećih 28 dana bolesnik je intravenski primao posakonazol i amfotericin B te je obavljena inferiorna maksilektomija. Maksilarni defekt trebao se rekonstruirati nakon završetka hematološkog liječenja, a u međuvremenu je pacijent opskrbljen opturatorom. Zbog lošeg općeg stanja bolesnika nije bilo moguće nastaviti s liječenjem leukemije presađivanjem alogenih matičnih stanica. Zbog toga je započeto liječenje blinatumomabom. Nažalost, u lipnju 2018. pacijent je umro zbog teškog hemoragičnog šoka i kardiopulmonalnog zastoja.

Budući da se koinfekcija gljivicama Aspergillus i Rhizopus iznimno rijetko vidi u usnoj šupljini, česte su dijagnostičke i terapijske dvojbe.

\section{Rasprava}

Akutne invazivne gljivične infekcije paranazalnih sinusa i okolnih tkiva kod imunokompromitiranog bolesnika progresivne su i imaju visok stupanj smrtnosti (8). Gode i suradnici (8) opisali su 37 bolesnika s akutnim invazivnim gljivičnim rinosinusitisom $\mathrm{i}$ istaknuli da je zahvaćenost nepca značajno povezana sa smrtnošću.

Postoji samo nekoliko slučajeva istodobne aspergiloze i zigomikoze u orofacijalnoj regiji $(1,2,9)$.

Torres-Damas i suradnici (1) izvijestili su o slučaju 78-godišnjeg pacijenta s dijabetesom tipa 2 i ketoacidozom kojemu je zbog gljivice Aspergillus fumigatus i mukormikoze nastala oteklina i paraliza desne strane lica, ptoza te nekrotični ulkus desne strane nepca. Chermetz i suradnici (2) opisali su slučaj 17-godišnje djevojke nakon liječenja rekurentnog glioma s kombiniranom aspergilozom i mukormikozom desne strane lica, sa zahvaćenim prednjim maksilarnim područjem i gornjim dišnim putovima.

Maiorano i suradnici (9) pisali su o slučaju aspergiloze i mukormikoze kod pacijenta s IV. stadijem Castlemanove bolesti, što se očitovalo kao ulceracija nepca koja je progresivno zahvatila palatalnu sluznicu i kosti, paranazalne sinuse i orbitu.

Iako su invazivne gljivične infekcije kod primatelja krvotvornih matičnih stanica glavni uzrok smrtnosti povezane s infekcijom, kod ovoga se pacijenta invazivna gljivična infekcija dogodila prije transplantacije krvotvornih matičnih stanica, tijekom postkemoterapijske aplazije.

Diferencijalna dijagnoza takvih slučajeva uključuje malignitet zbog čega je biopsija obvezna. Zbog visoke učestalosti gljivičnih infekcija kod imunokompromitiranih bolesnika, potrebno je obaviti mikrobiološka ispitivanja i identifikaciju uzročnika.

Liječenje tih lezija uključuje kiruršku resekciju zahvaćenih tkiva i protugljivične lijekove intravenski. Lijekovi izbora su posakonazol ili amfotericin B. U rezistentnim slučajevima 
Posaconazole or Amphotericin BS is the drug of choice. Caspofungine can be added in resistant cases. Nevertheless, the duration of the treatment is long (median 180 days) and the outcome is unpredictable, favorable in only $40-60 \%$ of the cases.

This case report highlights the importance of considering the coinfection with Aspergillus and Rhizopus genera in the orofacial area in patients with leukemia. može se dodati i kaspofungin. Uz to, liječenje je dugotrajno (medijan 180 dana), a ishod je nepredvidiv, povoljan u samo 40 do $60 \%$ slučajeva.

Ovaj prikaz slučaja ističe važnost razmatranja koinfekcije rodovima gljivica Aspergillus i Rhizopus u orofacijalnom području kod pacijenata s leukemijom.

\section{Sažetak}

Bolesnik u dobi od 54 godine s akutnom limfoblastičnom leukemijom upućen je u Zavod za oralnu medicinu. Imao je primarnu refraktornu bolest i liječen je prema protokolima HOVON 71 i HAM. Šesnaest dana nakon početka primjene protokola HAM, bolesniku se pojavila oralna tamnocrvena/ smećkasta lezija nepca i maksilarna vestibularna egzofitična lezija. Iz obiju su uzeti uzorci za biopsiju te su mikrobiološkom obradom potvrđeni Aspergillus fumigatus i Rhizopus genus. Liječenje bolesnika sastojalo se od inferiorne maksilektomije te intravenski posakonazola i amfotericina tijekom sljedećih 28 dana. Budući da se koinfekcija tim dvjema gljivicama iznimno rijetko pojavi u usnoj šupljini, česte su dijagnostičke i terapijske dileme.
Zaprimljen: 23. studenoga 2018. Prihvaćen: 28. kolovoza 2019.

Adresa za dopisivanje doc. dr. sc. Danica Vidović Juras, dr. med. dent.

Zavod za oralnu medicinu

Stomatološki fakultet Sveučilište u Zagrebu

Gundulićeva 5, 10000 Zagreb tel: 003854802124

dvjuras@gmail.com

Ključne riječi

oralne bolesti; mukormikoza; aspergiloza; imunokompromitiran domaćin leukemija

\section{References}

1. Torres-Damas W, Yumpo-Cárdenas D, Mota-Anaya E. Coinfection of rhinocerebral mucormycosis and sinus aspergillosis. Rev Peru Med Exp Salud Publica. 2015;32(4):813-7.

2. Chermetz M, Gobbo M, Rupel K, Ottaviani G, Tirelli G, Bussani R, Luzzati R, Di Lenarda R, Biasotto M. Combined Orofacial Aspergillosis and Mucormycosis: Fatal Complication of a Recurrent Paediatric Glioma-Case Report and Review of Literature. Mycopathologia. 2016;181(9-10):723-33.

3. Mölle M, Blaschke-Hellmessen R, Schuler U, Nowak R, Ehninger G. Disseminated aspergillosis and mucormycosis. A case report. Mycoses. 1996;39 Suppl 1:59-64

4. Davoudi S, Anderlini P, Fuller GN, Kontoyiannis DP. A long-term survivor of disseminated Aspergillus and mucorales infection: an in structive case. Mycopathologia. 2014;178(5-6):465-70.

5. Radowsky JS, Strawn AA, Sherwood J, Braden A, Liston W. Invasive mucormycosis and aspergillosis in a healthy 22-year-old battle casualty: case report. Surg Infect (Larchmt). 2011;12(5):397-400.
6. Pozo-Laderas IC, Pontes-Moreno A, Robles-Arista IC, Bautista-Rodriguez MD, Candau-Alvarez A, Caro-Cuenca MT, Linares-Sicilia MJ. Mixed invasive fungal infection due to Rhizomucor pusillus and Aspergillus niger in an immunocompetent patient. Rev Iberoam Micol. 2015;32(1):46-50.

7. Daenen S., van der Holt B., Dekker A., Willemze R., Rijneveld A., Biemond B., et al. Intensive chemotherapy to improve outcome in patients with acute lymphoblastic leukemia over the age of 40: a phase II study for efficacy and feasibility by HOVON. Leukemia. 2012;26:1726-29.

8. Gode S, Turhal G, Ozturk K, Aysel A, Midilli R, Karci B. Acute invasive fungal rhinosinusitis: Survival analysis and the prognostic indicators. Am J Rhinol Allergy. 2015;29(6):e164-9.

9. Maiorano E, Favia G, Capodiferro S, Montagna MT, Lo Muzio L. Combined mucormycosis and aspergillosis of the oro-sinonasal region in a patient affected by Castleman disease. Virchows Arch. 2005;446(1):28-33. 